Annales UMCS

Informatica

Lublin-Polonia

Sectio AI

http://www.annales.umcs.lublin.pl/

\title{
Identification of e-learning services in higher education
}

\author{
Tomasz Komorowski ${ }^{1 *}$ \\ ${ }^{1}$ Institute of Information, Technology in Management, University of Szczecin \\ Mickiewicza 64, 71-101 Szczecin, Poland
}

\begin{abstract}
The main purpose of this paper is to present the problem, identify goals and discuss higher education e-learning services. The basis for the discussion is the development of process approach to measuring operational efficiency and improving the quality of services. The paper presents various perspectives on e-learning and definitions of service efficiency. For the sake of service identification, one of the most common business processes classification, i.e. APQC Process Classification Framework, was employed. According to the approach suggested by the APQC in the article, there are two groups of processes. The first group consists of the operating processes of e-learning, and the second one - of management and support processes. Another section illustrates the example of e-exam service business model presented with the use of the map of business processes. It also sets out the assumptions and results of time simulation of e-exam service. The summary presents conclusions and suggested directions for further research.
\end{abstract}

\section{Introduction}

The strategy for the development of higher education system assumes, among other things, the effective use of academic and teaching staff (dependence of remuneration on the quality of teaching activity and scientific research), more efficient use of financial and human resources as well as improvement in the systems for the management of public higher education institutions (procedures for strategic and financial controlling) [1]. At the same time, factors determining future development of higher education in Poland explicitly indicate that e-services are becoming more and more popular, the computerization of universities is greater and e-learning is used more and more often during classes. Employers also consider the ability to communicate via the Internet and willingness to continue one's education (long-life learning) as major assets of employees

*tomasz.komorowski@live.wneiz.pl 
[2]. International research showed that e-learning treated as the additional form of teaching produced better effects compared to the traditional methods. This stems particularly from the value of e-learning courses and greater amount of time devoted to learning. The results of the research suggest that this form of education is becoming more and more popular, which is also the case in Poland.

Just as the number of IT applications is subject to growth, methods and tools used for determining the efficiency of higher education system are subject to change. The main e-learning processes consist of the following [3]:

- development of courses (production processes),

- teaching process (service processes),

- student service (support processes).

Process approach is a systematic identification of processes taking place in a given organization as well as effective management of these processes and their dependence. In line with the process management paradigm and due to the fact that educational offer is of a service character, a set of services that universities offer to their students and other services may be distinguished for each of the three aforementioned processes. The identification of services, their structure and dependence may be a basis for the effective management of business processes taking place at a given higher education institution.

\section{E-learning services as a set of processes}

E-learning services understood as organized educational activities making use of the latest tele-information technologies, including distance education via the Internet, are more and more popular in business, higher education and life-long learning. Many representatives of academic world are inclined to believe that progress in education can be made only due to the efficient use of modern technologies. Service activities are subject to change, which substantially enhances the phenomenon of virtualization that stems from, among other things [4]:

- growing globalization as well as mobility of students and academic teachers,

- growing importance of service quality,

- individualization of educational paths.

As management patterns have recently changed and evolved into process management and taken account of models used for designing service-oriented systems, it can be stated that this development trend will continue.

One of major problems with e-learning management is the lack of uniform model and explicitly defined processes of this form of knowledge dissemination. In the literature on the subject (see $[\mathbf{5}, \mathbf{6}, \mathbf{7}, \mathbf{8}]$ ) one may come across many different classifications of e-learning. The analysis of these classifications allows to define e-learning in the following way: as precise as possible reproduction of traditional educational process 
that absorbs IT technologies into its processes. As a consequence, only the means of content transfer, knowledge verification and communication are subject to change.

E-learning is the outcome of three different aspects [9]:

- IT technologies \& infrastructure,

- content of e-learning courses,

- e-learning services - all actions taken while carrying out e-learning processes.

Technologies, resources and infrastructure are the elements of education system. Educational content is both the product of certain processes (responsible for the creation of e-learning materials) and resource used while teaching. Depending on the context of a given process, the content plays the role of effect (output) or supports the process itself (input). E-learning services may be defined as a set of processes aimed at providing students with a widely understood education and stimulating the development of competence in a given field and with the use of modern tele-information technologies and resources (e.g. content, IT infrastructure etc.). Process approach to e-learning may affect not only management pattern followed in a given scope of activity, but may also be useful in designing the systems for traditional and distant learning.

\section{Identification of processes and services - objectives}

The main advantages following from the analysis and formalization of processes taking place in the organization are: better understanding of actions taken in the course of analysis and formalization as well as greater cooperation among individuals (workers, students, partners). Furthermore, the identification of processes allows to define objectives and quality policy pursued by higher education institutions. Business process mapping together with specifying the owners of the processes and their dependence makes it easier to prepare documentation essential for the efficient functioning of every modern organization. Source materials collected in such a way may be used for pursuing a number of optimization activities including:

- Optimization of e-learning services. Process model will allow to analyze all the actions and resources absorbed while accomplishing the objective, due to which potential losses can be eliminated (the quality of processes measured paying attention to the following losses: waste of time, quantitative excess and scale mismatch, waste of resources, poor organization, imperfect communication and limited information, limited number of activities pursued for the benefit of customers) [10].

- Creation of model for measuring and monitoring educational services (eliminating subjective appraisal as far as possible). The evaluation of educational process is based to a large extent on subjective opinions expressed in questionnaires, i.e. only general "impressions" gained by students are recorded. Such assessment seems inadequate and is widely criticized by academic staff. Distinguishing of services measuring and monitoring educational processes on 
the basis of e.g. logs from e-learning systems and other forms of data collection could be useful for preparing evaluation reports and assessing the quality of services in a more reliable way. Such services might also be adopted in a traditional model of education.

- Use of methods for determining service effectiveness that will contribute to greater operating and strategic effectiveness of higher education institution. The formalization and analysis of processes implemented in the organization may be a basis for employing various methods aimed at measuring the effectiveness as well as holistic methods that allow to assess investments in a certain perspective.

- Examination of the effect that e-learning services exert on organizational efficiency of a given higher education institution. The research referred to in the introduction proves that e-learning supports traditional learning to a great extent. Distinguishing of services will allow to use blended learning whenever necessary.

- Creation of the model for e-learning system based on the SOA paradigm. The context of system architecture is defined by the SOA (Service Oriented Architecture) paradigm that understands services as autonomous functionalities developed and made available within the framework of distributed systems both for the final user and other services.

\section{Types of processes and e-learning services}

American organization APQC (American Productivity and Quality Centre) and International Benchmarking Clearinghouse in cooperation with Arthur Andersen \& Co. consultancy firm developed a particularly popular classification of processes taking place in enterprises. According to this classification, twelve types of processes [11] may be divided into two groups, namely operating processes as well as management and support processes.

The classification was based on the document entitled "Process Classification Framework" published by American organization APQC and modified paying attention to e-learning services. Altogether, 261 processes were identified, each of which is directly or indirectly related to e-learning services.

\section{Tools for process modelling}

Graphical language (graphical diagrams) is the main tool for describing and modelling business processes. It includes block diagrams, Unified Modeling Language diagrams or Event-Driven Process Chain, etc. BPMN (Business Process Modeling Notation) is one of the most popular notations for process modelling. It is a graphic notation used for describing business processes and promoted by Business Process Management Initiative. It is becoming a practical standard for this description. BPMN has explicitly 
Pobrane z czasopisma Annales AI- Informatica http://ai.annales.umcs.pl

Data: 26/04/2023 10:09:03

Table 1. Classification of e-learning processes by APQC PCF.

\begin{tabular}{|l|l|c|}
\hline $\begin{array}{l}\text { Process } \\
\text { group }\end{array}$ & $\begin{array}{l}\text { Type of process by APCQ PCF } \\
\text { (modified for e-learning) }\end{array}$ & $\begin{array}{c}\text { Number of } \\
\text { processes }\end{array}$ \\
\hline \multirow{4}{*}{$\begin{array}{l}\text { Operating } \\
\text { processes }\end{array}$} & Develop Vision and eLearning Strategy & 15 \\
\cline { 2 - 3 } & $\begin{array}{l}\text { Design and manage Content for e-Courses } \\
\text { and eLearning Services }\end{array}$ & 9 \\
\cline { 2 - 3 } & Market and Sell Products and Services & 23 \\
\cline { 2 - 3 } & Deliver Products and eLearning Services & 27 \\
\cline { 2 - 3 } & Manage Customer Service & 9 \\
\hline \multirow{2}{*}{$\begin{array}{l}\text { Management support } \\
\text { services }\end{array}$} & $\begin{array}{l}\text { Develop and Manage Human Capital and } \\
\text { eLearning skills }\end{array}$ & 34 \\
\cline { 2 - 3 } & Manage Information Technology & 36 \\
\cline { 2 - 3 } & Manage Financial Resources & 12 \\
\cline { 2 - 3 } & Acquire, Construct, and Manage Property & 23 \\
\cline { 2 - 3 } & Manage Environmental Health and Safety & 20 \\
\cline { 2 - 3 } & Manage External Relationships & \\
\cline { 2 - 3 } & Manage Knowledge, Improvement, and Change & 34 \\
\hline
\end{tabular}

Source: own elaboration based on [11].

defined a set of graphical elements that enable one to create diagrams comprehensible to process designers, analysts and managerial staff (see [12]).

For the purpose of modelling business processes in e-learning, the integrated ADONIS package (Business Process Management Toolkit; Community Edition) was employed. ADONIS offers a wide range of various functionalities in the following operational areas of Business Processes: modelling, analysis, simulation, evaluation, documentation as well as import/export projects and data.

According to the BPMS Methodology, the approach adopted while implementing organizational projects involves [13]:

- Identification of products or services produced by the enterprise or its part being examined

- Identification of Business Processes that answer the question "with which processes or activities are these products or services provided?"

ADONIS software enables one to adopt the following types of models [13]:

- Product model - description of a product and its composition (product components).

- Company map - supports the illustration of business process models in a group or hierarchical order (a kind of navigation tree). The company map is the top level of order structure with the objective of obtaining an overview and identifying coherences between business processes.

- Business process model - Business Process Models represent process flows in an organization. The sequence of tasks is modelled with the use of activities 
that are needed to resolve a specific task. The control objects ("process start", "decision", "parallelism", "merging" and "end") and the "Subsequent" relation enable one to clearly map the tasks.

- Working environment model - describes the structure of an organization. Working Environment models can be built hierarchically with the use of working environment sub models e.g. to illustrate a detailed structure of working environment.

- Document model - contains documents (templates) utilized in the processes (input, output to activities etc.).

- Risk model - used for modelling risks within business processes. It can also be adopted for the generation of risk reports and process documentation. Risks are assigned to activities and can be controlled within the same or another process.

- Control model - refers to control activities via their generic control function or to risks in processes. It is plausible to create Risk - > Process -> ControlMatrix.

- IT system model - can be built hierarchically using IT system sub models e.g. to illustrate a detailed structure of an IT system.

- Business process diagram (BPMN) - provides a formal mapping to an execution language of BPM Systems.

- Use case diagrams - are often employed at the early stages of an IT project to support the analysis of requirements. In the Use case diagrams interactions between the systems and the involved parties are shown and described. The involved parties impose requirements on the system in order to reach goals.

Each of the aforementioned models can be used for modelling business processes. However, only four of them were employed to illustrate the example of e-learning service, namely company map, business process model, document model and IT system model.

\section{The example of business processes in e-learning}

Process management is based on process measurement that improves organizational efficiency. The system of process measures should take account of the main process attributes, namely:

- importance to customer,

- costs and lead time,

- flexibility,

- quality,

- importance to organization.

In order to illustrate e-learning service, e-exam was selected, i.e. one of less complex processes. E-exam was restricted to the model involving the verification of knowledge in a written form with the use of test/quiz including various questions and assessed 
automatically (by the system) and manually (by the teacher). Attention was not paid to the possibility of holding e-exams in the oral form via the Internet and with the use of design forms. Time and cost measurement (financial perspective and organizational efficiency) as well as reduction in the amount of time one spends waiting for exam results (from the perspective of teacher-student relation) were direct objectives of e-exam modelling. At this stage certain attributes were excluded, namely quality, flexibility and importance to customer/organization as they would not be subject to further examination.

Process modelling was based on the author's own experience and brainstorming with a team of researchers dealing with e-learning in the academic environment. The exam is held in a traditional way and in the electronic form (with the use of computers). It is a set of activities repeated in accordance with a given pattern and in a limited number of variants. The analysis paid attention to the procedure for holding the exam (issues such as providing students with suitable environment or resources, i.e. base of questions, sets of exam questions etc. were omitted).

E-exam service is a business process that consists of 3 sub-processes, 4 activities and 3 decision-making blocks (see figure below). Triangle with an arrow inside symbolizes a sub-process. As for the example under discussion, the following sub-processes were distinguished: "User authentication", "Contact with e-teacher" and "Manual test assessment". Each sub-process has its own structure and may consist of other subprocesses, thus represents a reference structure of dependence (e.g. sub-process "User authentication" consists of, among others, the following three sub-processes: "User logging", "Automatic reset of user password" and "Contact with administrator"). Apart from its name, the activities, represented by rectangles, have a number of attributes that enable one to describe each activity in detail, indicate links to documents, products and systems, and precisely determine the time and cost of each activity. The link to other objects in the model within the framework of the project as well as great potential for configuring simulation parameters contribute to greater accuracy and value of simulations carried out.

Virtually every process may be implemented in a number of variants. Decisionmaking blocks, represented by rhombus, allow to determine the probability that a given process will take place.

In order to estimate the amount of time needed for holding 1.000 exams (examining one thousand students in a given subject), the model of business processes was completed with data derived from the following sources:

- $\log$ for e-learning system at higher education,

- questionnaire survey addressed to students and academic teachers who use this form of examination,

- results of the analysis into the resources of e-learning system.

Logs were derived from 159 e-courses created on e-learning platform with registered 3740 users, 100 of whom were academic teachers. In the last semester, 76 exams (tests) were defined (including exams held before examination session, those held during the 


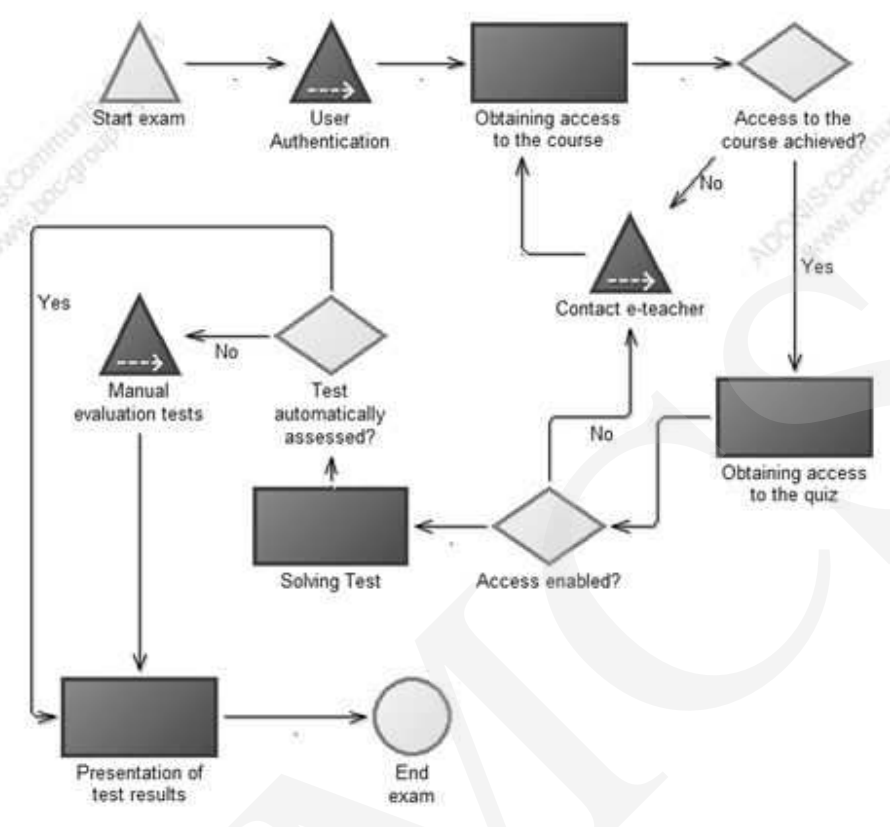

Fig. 1. E-exam service - model of business processes.

session and resit examinations). All in all, 874 tests were performed. All e-exams were held in a stationary mode, i.e. each student took the exam himself/herself in a computer room available at the university. It was not plausible to take e-exam.

Table below presents the results of calculations used for completing the simulation model of business processes in e-learning. The average time was determined with the use of data derived from the base of e-learning system and questionnaire survey (arithmetic average). On the other hand, probability was estimated on the basis of all event logs (e.g. false logs in) and the results of analysis into the resources of e-learning platform.

\section{Results of simulation experiment and summary}

Simulation experiment, i.e. holding a thousand exams, is a complex process lasting from the very beginning of the exam (entering the room, starting a computer and logging) till getting the results. The model is based on the assumption that working day lasts 8 hours and there is an infrastructural limitation, namely the number of computer workstations in the lab (e-exam may be taken by at most 20 people at a given time). The results (expressed in working days) are presented in the chart below (Fig. 2).

The chart indicates that the total time of 1.000 exams from student's perspective amounts to 7.32 days, which gives approximately 1.17 hours from the beginning of exam 
Pobrane z czasopisma Annales AI- Informatica http://ai.annales.umcs.pl

Data: 26/04/2023 10:09:03

Table 2. Data for simulation model of e-exam business process.

\begin{tabular}{|lcr|}
\hline Factor name & Unit & Value \\
\hline Average duration of test & minute & 23.25 \\
\hline Average run time of exam & minute & 10 \\
\hline Authentication error probability & $\%$ & $6.98 \%$ \\
\hline Solving problem of authentication time & minute & 3.4 \\
\hline Authorization error probability & $\%$ & $2.06 \%$ \\
\hline Authorization problem resolution time & minute & 0.933333 \\
\hline Probability of questions being evaluated by teacher & $\%$ & 0.049342 \\
\hline Average time for evaluation by teacher & minute & 8.25 \\
\hline Average waiting time for results & minute & 5.921053 \\
\hline
\end{tabular}

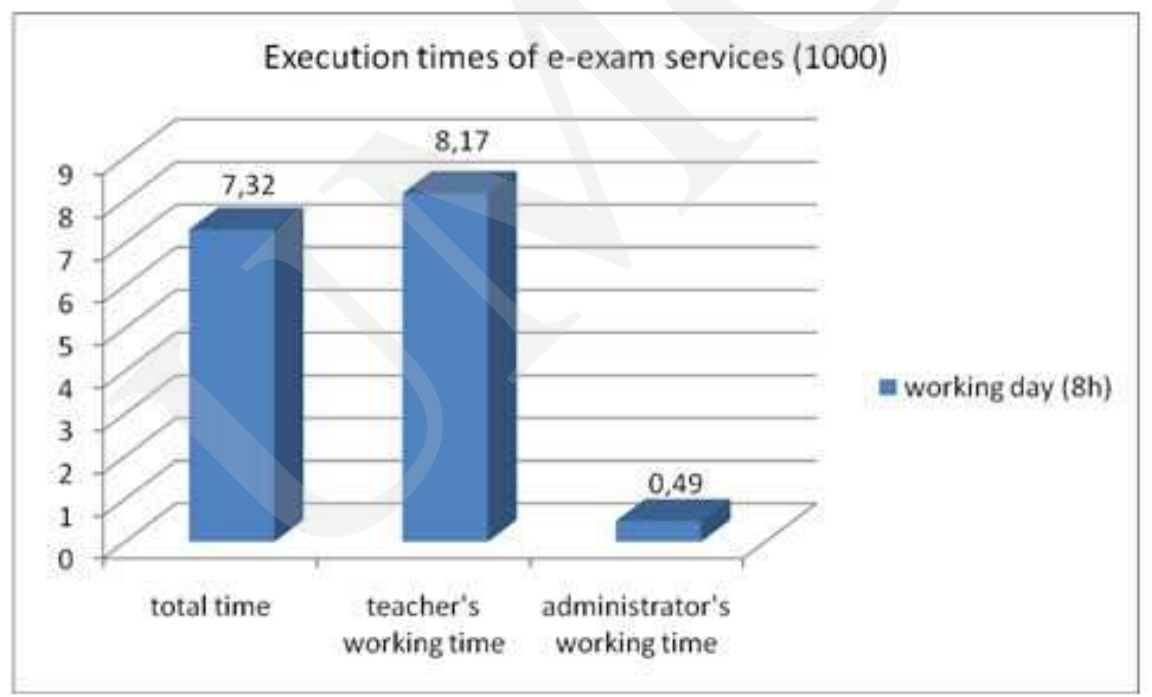

Fig. 2. Execution times of e-exam services.

till one gets the result. Teacher's working time, including extra-curricular activities, was longer and totalled 8.17 days, which means that one teacher would have to devote more than 8 working days to hold and assess 1000 exams using e-exam service. As for the example under discussion, administrator's absorption amounts to less than half a day. This time is attributed to administrative actions relating to problems with authorization and potential technical problems. Cost/time of so-called readiness to work was omitted here. This cost/time should be estimated for the actual duration of exams. 
Further investigation should involve completing the model with other processes and diagnosis of malfunctioning processes and sub-processes, based on the analysis of selected criteria for assessment [14]:

- Promptness - too long total time after which the desired effect is produced.

- Costs - too high costs incurred to accomplished particular tasks, resulting, among other things, from excessive working hours, accumulation of too many resources, using specialized services too often, i.e. even though no need arises.

- Quality - incompatibility frequently resulting from procedural negligence, lack of in-depth analysis and tests of solutions used.

- Customer satisfaction - incompatibility with customer's expectations resulting from the lack of comprehensive knowledge of needs and problems faced by future users.

- Flexibility - too rigid procedures that do not allow to take optimizing actions.

BPMN methodology and tools used for modelling e-learning services allow not only to carefully analyze and formalize business processes, but are also a basis for estimating the costs of particular services. The development of reference process models may be employed both for designing information systems within the framework of service-oriented architecture and taking managerial actions (process reengineering, optimization, communicating of strategy etc.).

The classification presented in the first section of the paper and based on the document entitled "Process Classification Framework" will be subject to further modification with special reference to e-learning services. The total of 261 identified processes would be enough to create the ideal model of services. Each process is directly or indirectly linked to e-learning services. However, they differ in significance. Therefore, the number of processes will be reduced considerably in the course of investigation (to about 30 ) so that the model is real and includes only the main elements. It is currently not possible to create a complete model due to time and budget limitations.

\section{References}

[1] Strategy for Higher Education System Development by 2020, Ministry of Science and Higher Education: Source: http://www.nauka.gov.pl/finansowanie/fundusze-europejskie/programoperacyjny-kapital-ludzki/projekty-systemowe/strategia-rozwoju-sw-do-roku-2020/

[2] Factors determining the development of higher education system in Poland in the future: globalization, demography and socio-economic changes in Poland. [In Polish] Sub report published by the consortium represented by Ernst \& Young Business Advisory and The Institute for Market Economics. November (2009); Source: http://www.nauka.gov.pl/fileadmin/user_upload/Finansowanie/fundusze_europejskie /PO_KL/Projekty_systemowe/20100727_Etap_2_uwarunkowania_rozwoju _SW_globalizacja_demografia_i_zmiany.pdf

[3] Wodecki A., Kontrola jakości procesów e-learningowych w kształceniu akademickim, in: Rozwój e-edukacji w ekonomicznym szkolnictwie wyższym, pod redakcją Marcina Dąbrowskiego i Marii Zając, Materials from all-Poland conference, 18th November 2004, University of Economics in Katowice. 
[4] Filipiak B., Panasiuk A. (red.), Przedsiębiorstwo usługowe. Zarządzanie, Wydawnictwo Naukowe PWN, Warszawa (2008): 30.

[5] Anderson T., Elloumi F.: Theory and Practice of Online Learning. Athabasca University (2004); online http://cde.athabascau.ca/online_book/

[6] Anderson R. S., Bauer J. F., Speck B. W.: Assessment Strategies for the On-line Class From Theory to Practice: New Directions for Teaching and Learning, Jossey-Bass (2002).

[7] Hyla M., Companion to E-learning, Oficyna Ekonomiczna, Warszawa (2005).

[8] Nojszewski D., E-learning Platforms in Polish Education Institutions, E-mentors 2 (2003).

[9] Zieliński Z. E., Computer Systems in E-learning Management, Zeszyty naukowe 2/2006. SCENO - Świętokrzyskie Centrum Edukacji Na Odległość. Kielce (2006).

[10] Kaszuba J., Zastosowanie modelowania procesów biznesowych w przedsiębiorstwach (In Polish), materials from the scientific conference "Business and IT process modeling in Poland and in the world - achievements and challenges", Warsaw School of IT Technology, Warsaw (2011).

[11] APQC Process Classification Framework (PCF) - Cross Industry - PDF Version 5.2.0; source: www.apqc.org/pcf

[12] Piotrowski M., Notacja modelowania procesów biznesowych podstawy Business Process Modeling Notation BPMN, Wydawnictwo BTC (2007).

[13] ADONIS CE software; In Polish: http://www.adonis-community.com

[14] Waćkowski K., Kowalczyk T., Using workflow/BPM tools for the automation of business processes [in Polish], in: materials from the seminar "Business and IT process modeling in Poland and in the world - achievements and challenges", Warsaw School of IT Technology, Warsaw (2011). 